Feasibility Study: Potential Enhancements for the LLNL Renewables Website

F. Kearns, M. Krawchuk, M. Moritz, S. Stephens,

N. Goldstein

January 29, 2008 
This document was prepared as an account of work sponsored by an agency of the United States government. Neither the United States government nor Lawrence Livermore National Security, LLC, nor any of their employees makes any warranty, expressed or implied, or assumes any legal liability or responsibility for the accuracy, completeness, or usefulness of any information, apparatus, product, or process disclosed, or represents that its use would not infringe privately owned rights. Reference herein to any specific commercial product, process, or service by trade name, trademark, manufacturer, or otherwise does not necessarily constitute or imply its endorsement, recommendation, or favoring by the United States government or Lawrence Livermore National Security, LLC. The views and opinions of authors expressed herein do not necessarily state or reflect those of the United States government or Lawrence Livermore National Security, LLC, and shall not be used for advertising or product endorsement purposes.

This work performed under the auspices of the U.S. Department of Energy by Lawrence Livermore National Laboratory under Contract DE-AC52-07NA27344. 


\title{
Feasibility Study: \\ Potential Enhancements for the \\ LLNL Renewables Website
}

\author{
by \\ Faith Kearns, Ph.D. \\ Meg Krawchuk, Ph.D. \\ Max Moritz, Ph.D. \\ Scott Stephens, Ph.D. \\ University of California, Berkeley \\ Noah Goldstein, Ph.D. \\ Lawrence Livermore National Lab
}

October 2007

Center for Fire Research and Outreach

firecenter.berkeley.edu 
This feasibility study investigates additional improvements / extensions to the LLNL Renewables Website. Currently, the Renewables Website focuses on wind energy in California. Future enhancements will include other renewable energy sources. The extensions described below are focused along two separate yet related avenues:

1. Forecasting wildfire risk in the regions of California where new development may occur, as a part of the "Million Solar Roofs" program.

2. Gaining a better understanding of the ecological components and potential of biofuels from forests in California.

These two avenues are further described in the sections below. Following is a technical description of the Center for Fire Research and Outreach computing and web service capabilities.

\section{FORECASTING WILDFIRE RISK IN CALIFORNIA}

As a part of the Governor's Million Solar Homes Initiative, a significant number of new buildings will have solar roofs. A large component of this development may be located in high wildfire risk areas in California. Understanding this wildfire risk and how it affects solar development is important for homeowners and decision-makers. Tools that could support better decision-making include:

1. Overlay of current and future urban footprint and wildfire risk data.

a. Current Wildfire Risk. Using the recently available Fire Hazard Severity Zone maps created by the California Department of Forestry and Fire Protection (CALFire) in collaboration with the Center for Fire Research and Outreach (CFRO) (address searchable web maps available at firecenter.berkeley.edu/fhsz), project future wildfire risk using pre-existing development projections from UCB faculty John Landis. These maps and similar approaches will allow citizens and decision-makers to better understand how wildfire risk will change as California's development footprint changes (Cleve et al. 2007). This type of information is vital for reducing future wildfire risks, helping to guide growth into wildland areas, and understanding potential climate change impacts.

b. Potential Wildfire Risk. Current approaches to mapping wildfire risk take the current or potential vegetation into account. Fire Weather is often overlooked, yet is a significant factor in determining the scale and location of large, destructive fires, particularly as a result of the Fall Santa Ana weather events in Southern California. This task will construct correlates between past fire and weather records, to produce maps of potential wildfire risk, as function of fire conditions and vegetation. These maps will be websearchable, as in the task above.

c. Climate Change-related Wildfire Risk. Development and climate change will also change fire regimes throughout the state. Understanding the effects of changes on overall fire regimes will ensure fire is included in scenarios of future growth. This task will entail 
producing potential future fire regimes under different Climate Change Scenarios, derived from current modeling work on climate variability and wildfire regimes (Parisien and Moritz, in review).

2. Web-based, search-by-address maps of layers described below.

a. Solar potential: Using a web-based search-by-address map format already developed by CFRO researchers, analysis tools for solar potential (from simple solar analyst tools) could easily be added. Solar potential maps would be overlain on the wildfire risks maps described above to give a clear understanding of the interplay between solar potential and wildfire risk.

b. Insolation/cloudiness: The National Oceanic and Atmospheric Administration (and other sources) has readily available maps of insolation / cloudiness that could be added to a web-based mapping application to allow decision-makers to better understand the best places to site solar facilities.

3. Web-based analyses of fire spread

a. HFire (program available for download at firecenter.berkeley.edu/hfire) is a raster-based, spatially explicit model of surface fire spread. This tool is currently being developed into web-based applications that could be integrated into a set of web-based tools that would allow users to understand how fire started in a particular location might spread (both speed and direction) and to simulate fire regimes over time.

b. Using HFire, pre-set simulations of various fire scenarios could be developed to give decision-makers a better understanding of potential fire effects in any geographic region in California.

4. Decision-making guidance and scenario-testing

a. Using the layers described in task 1 , several scenarios of future growth patterns could be captured and integrated into web-based decision-making tools. For example, "canned" scenarios of predicted growth patterns could be developed on decadal timelines (e.g., 2020, 2030, 2040) to examine growth patterns, potential for solar and other bioenergy, and wildfire risk.

b. As growth patterns play out, tree cover throughout the state will also change. Understanding this change is important for both solar and other bioenergy as well as wildfire risk. Building a tool to simulate how tree growth will change along with development patterns will allow decision-makers to understand future energy choices.

The following table (Table 1) summarizes potential tool development, intended users, and estimated costs. 
Table 1. Summary of wildfire risk forecasting tools.

\begin{tabular}{|c|c|c|c|c|c|}
\hline Title & Subtask & Product & $\begin{array}{l}\text { Short- or } \\
\text { long-term } \\
\text { funds }\end{array}$ & Intended users & Cost \\
\hline \multirow[t]{3}{*}{$\begin{array}{l}\text { 1. Current and } \\
\text { future risk, } \\
\text { using Landis' } \\
2050 \text { footprint }\end{array}$} & $\begin{array}{l}\text { Create layer using } \\
\text { combination of } \\
\text { CALFIRE's Fire } \\
\text { Hazard Severity Zone } \\
\text { maps and development } \\
\text { projection }\end{array}$ & $\begin{array}{c}\text { Digital } \\
\text { maps }\end{array}$ & Short-term & $\begin{array}{l}\text { Citizens, decision- } \\
\text { makers }\end{array}$ & $\$ 30,000$ \\
\hline & $\begin{array}{l}\text { Potential Fire Maps } \\
\text { using fire weather }\end{array}$ & & & & $\$ 50,000$ \\
\hline & $\begin{array}{l}\text { Climate Change } \\
\text { effects of future fire } \\
\text { regimes on } \\
\text { urbanization }\end{array}$ & & & & $\$ 50,000$ \\
\hline \multirow[t]{2}{*}{$\begin{array}{l}\text { 2. Address } \\
\text { Search }\end{array}$} & $\begin{array}{l}\text { Solar potential (simple } \\
\text { solar analysis) }\end{array}$ & $\begin{array}{l}\text { Digital } \\
\text { maps, } \\
\text { analysis }\end{array}$ & Short-term & $\begin{array}{l}\text { Citizens, decision- } \\
\text { makers, fire } \\
\text { operations } \\
\end{array}$ & $\$ 5,000$ \\
\hline & $\begin{array}{l}\text { Maps of insolation \& } \\
\text { cloudiness (from } \\
\text { NOAA or other } \\
\text { products) }\end{array}$ & & & & $\$ 20,000$ \\
\hline $\begin{array}{l}\text { 3. Integration of } \\
\text { Hfire into } \\
\text { website for } \\
\text { evaluation of } \\
\text { the siting and } \\
\text { growth patterns } \\
\text { of development }\end{array}$ & $\begin{array}{l}\text { Enabling "pre-cooked" } \\
\text { fire scenarios to be run } \\
\text { for any geographic } \\
\text { region in California }\end{array}$ & $\begin{array}{l}\text { Scenario } \\
\text { testing via } \\
\text { the web }\end{array}$ & Long-term & $\begin{array}{l}\text { Decision-makers, } \\
\text { fire operations }\end{array}$ & $\$ 50,000$ \\
\hline \multirow[t]{2}{*}{$\begin{array}{l}\text { 4. Decision- } \\
\text { making } \\
\text { guidance }\end{array}$} & $\begin{array}{l}\text { Build pre-set scenarios } \\
\text { that allow users to } \\
\text { choose future growth } \\
\text { scenarios }\end{array}$ & $\begin{array}{l}\text { Decision- } \\
\text { making } \\
\text { guidance } \\
\text { via the } \\
\text { web }\end{array}$ & Long-term & $\begin{array}{c}\text { Citizens, decision- } \\
\text { makers }\end{array}$ & $\$ 50,000$ \\
\hline & $\begin{array}{l}\text { Tree cover - remote } \\
\text { sensing - for future } \\
\text { development - tool }\end{array}$ & & & & $\$ 50,000$ \\
\hline
\end{tabular}

\section{Biofuels in CALIFORNiA FoRESTS}

Selective tree thinning is an often-utilized forest management tool for wildfire reduction and ecosystem in California's forests. This harvested resource may have added benefits for energy production from the biomass and carbon sequestration. A series of models and analyses is needed to quantify the potential for biofuels production on terrestrial landscapes - to determine where it is feasible and where it is less likely to succeed because of fire hazard considerations and to evaluate options under climate change scenarios. These analyses will be crucial for both 
natural and plantation-type systems. Each of these analyses hinges on quantifying the spatiotemporal environmental controls on fire-vegetation interactions, both currently and in the future. Therefore, we propose:

1. An assessment in hectares of how much forested land is available for biomass harvest in California.

a. Many of the datasets needed to quantify the amount of biomass available for harvest already exist and the CFRO has begun preliminary work to quantify available biomass streams. We also need to understand where this biomass currently goes and the feasibility of siting generation plants in economically viable areas.

b. In addition to biomass supplies, understanding how best to utilize the energy from wood biomass is important to decision-making. The amount of energy produced differs between technologies for utilization - an assessment of how many kW current and future forests can generate is important.

2. A pilot project completed in a forested area of California. The area should have good harvesting to biomass energy potential (i.e., near a facility that can burn the trees), and should be in a location where different thinning scenarios and natural regeneration rates (including fire return interval) can be understood. CFRO faculty Scott Stephens is a co-PI on the Sierra Nevada Adaptive Management Project, a large-scale research program that directly addresses the trade-offs involved in different types of fuel reduction treatments, an issue that Stephens has been involved in throughout his career. This type of work can be used to quantify the streams of woody materials that can be removed sustainably from California's forests.

3. An assessment of the forestry-to-biomass industry in California, given different fire regimes, or burning scenarios.

There is already some active biomass conversion taking place in California. However, it is not yet economically feasible. There is the potential that subsidies may be needed to get this sector fully functioning as it is still not a real option for many rural communities. As fire regimes change with development, land use and climate changes, understanding the potential for biomass production will be more difficult. Developing scenarios that include existing spatial heterogeneity in the risk of fire and the potential effect of biomass removal on subsequent fire risk will help to guide decision-making.

Recent work by CFRO takes a burn probability modeling approach developed by Parisien and Moritz (in review) that quantifies spatial heterogeneity in the recent historical patterns of observed fire and uses this surface to calibrate annual burn probabilities for northern California. The burn probability approach is a first step in the development of robust methods that incorporate empirical estimates on the spatial variability of fire risk into project-level decision making. Project locations with high burn probabilities describe areas that are more likely to experience fire, and therefore represent added risk and uncertainty in their provision of biomass. The relative risk of fire can be used to optimize the location of potential biomass 
processing sites conditional on existing fuel sources, infrastructure and the likelihood of natural disturbance.

Burn probabilities can also be used in project-level simulation experiments to determine the effect of fuel treatments (e.g., biomass removal) on future fire probability. The long-term risk of fire at a given location may be influenced by vegetation modification in the surrounding landscape through biomass removal in the short-term. The amount and configuration of biomass removal ("fuel treatments") would be simulated in landscape models to compare fire activity between treated and reference forest conditions.

As a first step, the existing product needs to be extended to cover the entire state. Future development of the burn probability approach could involve analyses to quantify meso-scale climate oscillations (e.g., climate and fire trends over periods of five to ten years) whose inclusion fine-tunes long-term burn probability estimates (Waller 2007). The fine-tuned burn probability estimates for each project area would be used to calibrate fire activity simulated with landscape fire models, such as FlamMap (Finney 2006) or HFire (Morais 2001). We propose the incorporation of climate change estimates into the weather modules of landscape fire models as an indicator of potential future conditions, for example by adjusting weather data with expected trends from regional or global climate models.

The following table (Table 2) summarizes potential tool development, intended users, and estimated costs. 
Table 2. Summary of biofuels tools.

\begin{tabular}{|c|c|c|c|c|c|}
\hline Title & Subtask & Product & $\begin{array}{l}\text { Short- } \\
\text { or long- } \\
\text { term } \\
\text { funds }\end{array}$ & Intended users & Cost \\
\hline $\begin{array}{l}1 \mathrm{a}- \\
\text { Assessment of } \\
\text { current } \\
\text { biomass utility } \\
\text { in CA }\end{array}$ & $\begin{array}{l}\text { Quantify available } \\
\text { biomass streams }\end{array}$ & $\begin{array}{l}\text { Maps of } \\
\text { available } \\
\text { biomass }\end{array}$ & $\begin{array}{l}\text { Short- } \\
\text { term }\end{array}$ & Decision-makers & $\$ 25,000$ \\
\hline $\begin{array}{l}\text { 1b - } \\
\text { Forecasting } \\
\text { current and } \\
\text { future } \mathrm{kW} \\
\text { from forests }\end{array}$ & $\begin{array}{l}\text { Assessment of kWs } \\
\text { current and future } \\
\text { forests can generate }\end{array}$ & $\begin{array}{l}\text { Maps of } \\
\mathrm{kWs} / \\
\text { landscape }\end{array}$ & $\begin{array}{l}\text { Short- } \\
\text { term }\end{array}$ & Decision-makers & $\$ 15,000$ \\
\hline $\begin{array}{l}2 \text { - Pilot } \\
\text { model project } \\
\text { of biofuels } \\
\text { streams }\end{array}$ & $\begin{array}{l}\text { Quantify woody } \\
\text { biomass that can be } \\
\text { sustainably removed }\end{array}$ & $\begin{array}{l}\text { Data / } \\
\text { example } \\
\text { of concept }\end{array}$ & $\begin{array}{l}\text { Long- } \\
\text { term }\end{array}$ & Decision-makers & $\$ 80,000$ \\
\hline \multirow{3}{*}{$\begin{array}{l}3- \\
\text { Assessment of } \\
\text { CA forestry to } \\
\text { biomass } \\
\text { industry }\end{array}$} & $\begin{array}{l}\text { Extension of burn } \\
\text { probability mapping } \\
\text { to the State of } \\
\text { California }\end{array}$ & $\begin{array}{l}\text { Burn } \\
\text { probability } \\
\text { surface }\end{array}$ & $\begin{array}{l}\text { Short- } \\
\text { term }\end{array}$ & $\begin{array}{l}\text { Decision-makers, } \\
\text { future research }\end{array}$ & $\$ 5,000$ \\
\hline & $\begin{array}{l}\text { Research and } \\
\text { development of burn } \\
\text { probability mapping } \\
\text { to include near term } \\
\text { and long term } \\
\text { changes in climate }\end{array}$ & $\begin{array}{l}\text { Updated } \\
\text { burn } \\
\text { probability } \\
\text { surfaces }\end{array}$ & $\begin{array}{l}\text { Long- } \\
\text { term }\end{array}$ & $\begin{array}{l}\text { Decision-makers, } \\
\text { future research }\end{array}$ & $\$ 50,000$ \\
\hline & $\begin{array}{l}\text { Project-level } \\
\text { simulations to } \\
\text { determine the effect } \\
\text { of biomass removal } \\
\text { on fire probability }\end{array}$ & $\begin{array}{l}\text { Decision } \\
\text { making / } \\
\text { Integrated } \\
\text { accounting }\end{array}$ & $\begin{array}{l}\text { Long- } \\
\text { term }\end{array}$ & $\begin{array}{l}\text { Decision-makers, } \\
\text { Future research }\end{array}$ & $\$ 75,000$ \\
\hline
\end{tabular}

\section{CFRO COMPUTING AND WEB SERVICES}

The CFRO computing services includes a group of ten workstations, networked in cooperation with the Berkeley Geospatial Imaging and Informatics Facility (GIIF). The GIIF maintains two servers in a secure location at the Oxford Tract (near the UCB campus). Data from the secure facility is also backed up off-site. 
The two servers work in cooperation to facilitate web-based mapping applications. The first server is a high-capacity data server running Apache, and the second is a 700GB map server. The servers are maintained by a full-time Computer Resource Specialist employed by the GIIF and overseen by a facility manager.

Data is organized as follows:

- $\quad$ Spatial data is stored in a PostgreSQL/PostGIS database, perl and php scripts are used to update and query the database.

- Mapserver, an open source web mapping program, renders images from a number of spatial data formats (.shp, .tiff, coverages, postGIS).

o Mapserver has simple integration with web mapping service allowing use of third party imagery and data; and

o Simple text map-file tells mapserver how the map image is rendered (what layers, projection, data source, legend classes, etc.).

- KaMap is a javascript interface to Mapserver:

o Uses the same map-file through Mapserver;

o Google-maps like interface; and

o Once an image is drawn by Mapserver, it is stored so subsequent access is very fast.

- Geocoding is completed using an open source approach - the map interface connects to a Yahoo Maps database via a javascript, ensuring that addresses are as current as any commonly used web-mapping program.

- The imagery served is from the National Agricultural Imagery Program (NAIP), which is freely available via the USDA. CFRO staff has created a web mapping service allowing any server to make use of the NAIP imagery on the GIIF server without having to duplicate this large dataset on their own server (similar to creating your own Google Maps interface using the Google API).

- Data can be included from multiple parties using an innovative approach that allows anyone with the ability to edit a basic spreadsheet to contribute to web content (Pedersen et al. 2007).

The servers can be replicated, with software and hardware costs totaling approximately $\$ 30,000$ (not including staff time). 
CFRO websites include:

Center for Fire Research and Outreach - firecenter.berkeley.edu

Fire Information Engine Toolkit - firecenter.berkeley.edu/toolkit

Homeowner Interactive Wildfire Assessment - firecenter.berkeley.edu/homeassessment/

HFire Fire Spread Model - firecenter.berkeley.edu/hfire/

California Fire Hazard Severity Zone Webmaps - firecenter.berkeley.edu/fhsz (developed for CALFire)

CFRO websites pages are viewed at an average rate of 3,000/week, with close to 50,000 requests in 2007 so far - this number is much higher than for comparable organizations.

\section{REFERENCES}

Cleve, C.T., N.M. Kelly, F.R. Kearns, and M.A. Moritz. 2007. Classification of urban environments for fire management support: A comparison of pixel- and object-based classifications using high-resolution aerial photography. Accepted, Computers, Environment, and Urban Systems.

Finney, M.A. 2006. An Overview of FlamMap Fire Modeling Capabilities. In: Andrews, Patricia L.; Butler, Bret W., comps. 2006. Fuels Management-How to Measure Success: Conference Proceedings. 28-30 March 2006; Portland, OR. Proceedings RMRS-P-41. Fort Collins, CO: U.S. Department of Agriculture, Forest Service, Rocky Mountain Research Station. p. 213-220.

Morais, M. 2001. Comparing Spatially Explicit Models of Fire Spread Through Chaparral Fuels: A New Algorithm Based Upon the Rothermel Fire Spread Equation. Master's Thesis, University of California, Santa Barbara.

Parisien, M. and M.A. Moritz. In review. Environmental controls on the distribution of wildfire at multiple spatial scales. Ecological Monographs.

Pedersen, B.S.*, F.R. Kearns*, and N.M. Kelly. 2007. Methods for facilitating web-based participatory research informatics. Ecological Informatics 2(1):33-42. (*denotes equal contribution)

Waller, E., M. Parisien, M. Krawchuk, and M. Moritz. 2007. Quantifying Expected Area Burned for Carbon Accounting Protocols. Center for Fire Research and Outreach white paper. 